\title{
Minding (About) the Gazan Border in Contemporary Palestinian Literature
}

\section{Claire Gallien}

\section{(2) OpenEdition \\ 1 Journals}

Electronic version

URL: https://journals.openedition.org/ces/4753

DOI: $10.4000 /$ ces.4753

ISSN: 2534-6695

Publisher

SEPC (Société d'études des pays du Commonwealth)

\section{Printed version}

Date of publication: 1 September 2016

Number of pages: $57-68$

ISSN: 2270-0633

\section{Electronic reference}

Claire Gallien, "Minding (About) the Gazan Border in Contemporary Palestinian Literature",

Commonwealth Essays and Studies [Online], 39.1 | 2016, Online since 05 April 2021, connection on 19 June 2021. URL: http://journals.openedition.org/ces/4753 ; DOI: https://doi.org/10.4000/ces.4753

\section{(c)}

Commonwealth Essays and Studies is licensed under a Licence Creative Commons Attribution - Pas d'Utilisation Commerciale - Pas de Modification 4.0 International. 


\section{Minding (About) the Gazan Border in Contemporary Palestinian Literature}

The Gazan border, as both a highly topical and sensitive issue, embodies the threatened state of Palestinian life at large and is central to contemporary Gazan writers and artists, whether they live inside or outside Gaza. In a sense, their art and literature seem to be trapped by the ongoing conflict with Israel and the current political situation in the region, to which they cannot but respond. As I highlight in the article, not only does fiction expose the violence and suffering of Gazan life under siege, it also challenges territorial fragmentation by transgressing the colonial map imposed by Israel and by defining counter-geographies.

The creation of Israel in 1948 and its expansion in 1967, to include the West Bank, Gaza, and the Golan Heights, and in 1982 South Lebanon, meant that it superimposed itself onto the already-existing country of Palestine and de facto appropriated its territory, destroyed Palestinian villages, erased their names, and redrew its borders.

In the photography essay Under the Last Sky, Edward Said highlights specific points regarding the Palestinian border - that its mapping is not in the hands of the Palestinians themselves but of Israel; that the borders are not stable but under threat and shifting with the on-going settlement policy in the West Bank and Jerusalem; and finally, that the imposition of the Israeli/Palestinian border has created further divisions of Palestinian territory and society between those Said called the Palestinians of the Interior (or Palestinian Israelis) and of the Exterior, namely the Palestinians who live outside the state of Israel, in exile as Palestinians of the diaspora or as refugees, who fled Israeli invasions and settled in neighbouring Arab states and in the Gaza Strip, and as Palestinians living in zones A and B of the West Bank (Said, After the Last Sky 51-3).

In 1999, when the book was published, Said described the Palestinians remaining within the newly formed borders of Israel as living "on the edge, under the gun, inside the barriers and kasbahs" (51). The interior is in the case of historic Palestine and for Israeli-Palestinians, a place of exclusion, danger, and violence. A lot of what Said depicted then is now largely applicable to Palestinians "of the exterior" as well. The divisions between them are no longer established along the lines of exilic versus resistant life - although Said was very far from implying that resistance stopped at the border - or between those who left and those who, in the language of Palestinian resistance, retained their sumud or steadfastness. Rather, the difference lies in the degree of violence of Israeli interventions, whether the land is invaded by the army and placed under siege as in the case of Gaza, or its territory eaten piecemeal and new walls serving the purpose of colonization erected, as in the case of the West Bank. Palestinians "of the exterior" and living under Palestinian authority are also now "under the gun."

This on-going process affecting Palestinians of the first, second, and third generations after the Nakba has had repercussions on Palestinian local and diasporic art and literature. In particular, the question of the Gazan border, placed under threat, attack, and siege, has become a crucial topic in contemporary Palestinian literature both in English and in Arabic. Thus, contrary to the poststructural glorification of borderlessness and hybrid lives present in postcolonial studies, the question of the border both 
in literature and on the ground is crucial to understanding the Palestinian predicament and its artistic expressions.

I would like to explore in the course of this article the ways in which contemporary Gazan literature not only minds (about) the border but also articulates counter-narratives that, conjoined with the struggle of a people, turn into resistant moves. Thus, Edward Said's position on resistance and grace does not only work one way but may actually function as a palindrome - resistance bestows grace and grace produces resistance; while suffering and resistance put those suffering and resisting in a state of "grace" compared to the rest of us, art itself may not only reflect this violence but also resist it.

Thus, in order to examine the resistance of form, this article engages with the issues raised by singularizing the Palestinian experience and reproducing without questioning it the split imposed between the Palestinians min al-dakkhil (of the interior), min al-khârij (of the exterior), and fil-ghurba or manfa (in exile). It examines the politics of representation of the border in prominent works of Palestinian literature ${ }^{1}$ produced in the last ten years (between the election of Hamas in 2006 and now) and argues that rather than reproducing divisions and the violence of exclusions and wars, texts and canvases are established as "temporary autonomous zones" where existing systems of control are evaded and subverted, borders redrawn and Palestine reconfigured.

\section{Divisive Borders, Shared Tropes}

For obvious historical reasons the question of Palestine today is a question of and about borders. Palestine has borders but these do not correspond at all to the borders drawn in the 1947 UN Partition Plan or to the 1949 Green Line, which refers to the borders agreed upon between Israel and its neighbouring Arab countries after the 1948 war. With the 1949 agreement, the borders of Israel extended far beyond those of the Jewish State ${ }^{3}$ and deprived Palestine of its northern territory, significantly reduced its maritime border and its border with Egypt, and broke the territorial continuity between the West Bank and the portion of land which in 1949 came to be known as the Gaza Strip. The Green Line remained the border recognized by both Israelis and Palestinians until 1967, when the Six Day War broke out and Israel conquered the West bank and Jerusalem, the Gaza Strip, the Golan Heights and the Sinai Peninsula. Since then, Israel has eaten away at Palestinian land. The issue today for Palestinians is a return to the pre1967 borders as a condition for peace, along with a return of all Palestinian refugees and a termination of the blockade imposed on the Gaza Strip.

1. Of course the notion of prominence is highly problematic in the sense that the value attributed to a literary work is dependent on culturally defined notions of taste and judgement. What I take to be prominent may not be what Gazans would define as such, except Gazans who use the same tools to analyze and appreciate what literature is. However, what I am interested in in this article is what Gazans project of themselves to the wider world and most importantly to the West, the kind of writing back to Western media and Western postcolonial theory. Thus, I have chosen works widely circulated through translation in English.

2. The term is borrowed from anarchist writer and poet Hakim Bey. The linchpin in Bey's argument is that art needs these temporary autonomous zones, free from the formal structures of power and control, in order to become truly creative. TAZ are established temporarily on the borders between controlled territories and their non-permanence is for Bey crucial in order to evade the encroachment of socio-political structures of power. The argument I would like to develop in this article is that Palestinian texts may be interpreted as temporary autonomous zones, created on the cracks of established boundaries, in order to subvert them. Plan.

3. In 1949, Israel held $78 \%$ of Mandate Palestine as opposed to the $56 \%$ initially proposed in the 1947 UN Partition 
The question of the Palestinian border remains unsolved and remains a highly contested and complex issue and the cause of a national struggle, the reason for outbreaks of violence and military interventions, and the focus of media attention.

As it stands today, it both divides and unites the Palestinian nation. It is geographically divisive and all the more so after the 2006 blockade imposed on Gaza, which repeats in an intensified mode the situation for Palestine at large. The poem "The earth is closing on us," written by Mahmoud Darwish, expressed, when it was written in 1986, the situation of Palestinian people pushed off their land and forced into exile beyond the seas. In the poem, the border is presented as a frontier moving forward, but the trope is subverted - instead of opening up onto wider territories it closes people down and forces them to flee and take refuge on the edge of the earth, until they reach what Darwish calls "the last passage," "the last space," or "last frontier," (13) where they are ready to die and give their blood for their nation so that olive trees, which are the symbols of the Palestinian nation, may grow.

Considering the crucial function of borders in Palestinian history, not only in terms of protection and control, but also in terms of national unity - or more specifically of national identity through the recovery of territorial continuity - it is of no surprise that the paradigm, also containing the themes of displacement, siege, every-day life under occupation, fragmented or split identity, and return, should feature so prominently in Palestinian literature and that borders should repeatedly re-emerge as lines of tension, fracture, and intense violence.

In the title of this article, the term "minding" is to be understood as, according to the $O E D$, "to be concerned with." As opposed to other postcolonial literatures centred on Bhabha's concepts of hybridity and dissemination, ${ }^{4}$ Palestinian authors and critics tend to frame their narratives in terms reminiscent of independence struggle and identify themselves more readily with Third World literature than with postcolonial literature. ${ }^{5}$ The border functions thus as a shared reality and a shared literary trope.

\section{Bearing Witness: The Gazan Writer as Scribe}

As Atef Abu Saif, the editor of a collection of short stories entitled The Book of Gaza, argued: "Palestinian literature [...] has been the faithful scribe of [the Palestinian people's] history, events, and tragedies, of the details of their displacement and refugeedom" (ix). The choice of terms is significant here. Instead of using the term "novelist," or other designations indicating original creation, Abu Saif resorts to the traditional figure of the scribe and the imitative nature of his art. Palestinian writers, and more particularly here in the frame of his collection, Gazan writers, are thus grounded in quotidian life and their fields encompass the local. Abu Saif seems to write off flights of imagination and

4. It is essential to underline that Homi Bhabha represents only one specific branch of postcolonial studies influenced by Derridean poststructuralism and not the entire field. The other main branch takes on a more materialist perspective and was developed by Benita Parry and the Subalternist group in Indian historiographical studies.

5. This argument has been very persuasively put forward by Anna Bernard in Rhetorics of Belonging. Borrowing their title from Neil Lazarus's 2011 article for the journal Race and Class, the authors and editors Anna Bernard, Ziad Elmarsafy and Stuart Murray of What Postcolonial Theory Does not Say identify Palestine as one of the "occluded" (4) territories of postcolonial theory and explain the situation by emphasizing the fact that national narration remains central and that Palestinian critics and writers often refuse or very reluctantly resort to the postcolonial category, which they believe conceals the colonial nature of the Israeli state. See also Salah Hassan, Gil Hochberg, Patrick Williams, and Joseph Massad, Ella Shohat, and Rebecca Stein. 
to have set realistic reporting as the sole and permitted mode of writing in a context of war and emergency or in a context of social and political deprivation, where literature has to be committed or otherwise cease to exist. However, what may slip the attention of English readers is that by designating Palestinian writers as scribes, Abu Saif also links Gazan literature to the larger tradition of modern Arabic literature influenced by Mahfuzian realism ${ }^{6}$ and thus connects the local with a pan-Arab vision of literature.

For instance, the first generation of Gazan writers usually worked in refugee camps and in the field of education and wrote "stories of exhausted workers who stood in long queues at the Erez crossing to work in Israel, stories of curfews and cordons imposed on camps, stories of prisoners' suffering [...] stories of challenges, determination, solidarity, and cooperation between people [...]. They wrote of their lived reality, and they did so honestly" (Abu Saif, The Book of Gaza x). The first generation of Gazan writers told of the plight of their people and Abu Saif reinterprets their activities in terms of a moral duty and commitment. This phase encouraged a literature that reflected historical events with little possibility of moving out of the moral imperative of representation, thus repeating the fettered condition which was imposed upon them in the first place. Neither flights of fancy inspired by the tutelary figure of Shahrazad, nor postmodernism and deconstruction, seemed adequate tools to resist and subvert the discourse of the enemy in a context of on-going conflict with Israel.

As far as Gazan writers are concerned, the moral and discursive imperatives to report on their reality, in order to reclaim what has been stolen from them, both in the physical and in the discursive senses of the term, by other forms of coverage, for instance Israeli state propaganda and Western mass media, has had the same effect of restricting Gazan literature to the experience of Gazan life, thus reinforcing its insularity. For instance, in Gaza Writes Back (2013), the short stories written in English in the wake of Operation Cast Lead are presented as responses to the Israeli blockade and invasion and also as counter-narratives to its media coverage. They are, in the words of the editor Refaat Alareer, "an attempt to engrave in the writers' own memories and those of others the atrocities or rare moments of hope that the stories capture" "Narrating Palestine" 533) The short stories function as a form of catharsis for a population living under siege and thus writing with a sense of urgency in alternative discourses to what Edward Said identifies, in The Question of Palestine, as the hegemonic coalescence of Zionism and Western liberalism. Said warned against this entanglement, which was meant, according to him, to achieve the writing off of Palestinians, turning the Arab into "a nonperson as much because the Zionist had himself become the only person in Palestine," (37) and to impose silence on them: "Zionism always undertakes to speak for Palestine and for the Palestinians; this had always meant a blocking operation, by which the Palestinian cannot be heard from (or represent himself) directly on the world stage" (39).

However, the prevalence and urgency of the mimetic imperative may reduce the value of such narratives outside the time and place of conflict. The danger for Palestinian literature, and for Gazan literature in particular, is to become twice embargoed and siphoned off to respond to military assaults or to react to the overt and latent

6. Naguib Mahfouz, who pioneered the genre of the Arabic novel, had a first phase in his career, revolving around the publication of The Trilogy (1956-57), and where he developed a style marked by a blending of social and psychological realism. His influence was so great in this style and mode of writing that the term "Mahfuzian realism" was coined and used by literary critics, such as Walid Hamarneh and Salma Khadra Jayyusi. 
manifestations of colonialism/Orientalism, subjected not only to a context of war and attrition which has had a major impact on the narrative choices of its authors, but also to the demands of the global literary market and its scopic desire for the inside view. In other words, writing back to colonialism may prevent the emancipatory act of writing beyond it. Well aware of this conundrum, Anna Bernard wrote of the awareness of both Palestinian and Israeli writers that they are expected to "narrate" the nation: "They cannot but respond, even if negatively, to this overwhelming expectation, and to the tremendous political and intellectual responsibility that it implies," (Bernard, Rhetorics 26) and that, in such a context, the postcolonial imperative to write off the nation acts as a dangerous remnant of the past and runs counter to Palestinian and Israeli demographic imaginaries.

In such cases, the border between reportage and fiction tends to disappear and the voice of the author tends to slip and supersede the voice of the narrator. For instance, Sarah Ali ends her short-story "The Story of the Land" with a call reminiscent of the rhetoric of activism: "Between my father and his Land is an unbreakable bond. Between Palestinians and their Land is an unbreakable bond. By uprooting plants and cutting trees, continually, Israel tries to break that bond and impose its own rules of despair on Palestinians. By replanting their trees over and over again, Palestinians are rejecting Israel's rules" (64). The same is true of certain passages in Out of it (2011), the first novel by British Palestinian novelist Selma Dabbagh, which could be read as inserted for the instruction of Western readers still unfamiliar with the Palestinian/Israeli conflict. In chapter 6 for instance, the narrator quotes lengthy extracts from Sabri's doctoral dissertation on the first intifada or provides dialogues in which Rachid, the second brother, is engaged with activists, professors, or friends in England, in order to update the reader on the history of the conflict.

Interestingly enough, the choice of language may have some impact on the frame and on the choice of topics addressed in the anthologies. The Book of Gaza is a book in translation, its chronological frame is larger than in Gaza Writes Back, encompassing Gazan literature from the Nakba onward, and it is less concerned with the immediate effects of the attacks on the Gazan borders than with examining the long-term effects and psychological trauma suffered by individuals living under siege. In "You and I" by Asmaa al-Ghul, the reader follows the stream of consciousness of the main character who, in order to ward off pain, keeps her mind busy counting "contiguous and incidental things: successive drains; the storeys of building, their windows, balconies, electricity pylons, the doors of closed shops" (98). The story opens and ends with the exact same paragraph, thus symbolically representing the mental trap in which the character is caught, her obsessive repetitions and returns, echoing the state of consciousness of a whole nation. In another short story, namely "The Cloak of the Sea," written by young author Nayrouz Qarmout, the motif of the Gazan sea is reinvested vertically - it is not a place of open vistas but of drowning for the main female protagonist - to represent social conservatism impairing the everyday life of Gazan individuals. The emphasis is placed here again on the long-term effects of war, the state of siege, and the social disintegration implied by them rather than on the latest events. 


\section{Reconfiguring Space: Gaza and Hyphenated Geography}

However, the border is not only what isolates Gaza but is also what unites it with other Palestinians. Glenn Bowman reminds us that the difference between Gaza and the West Bank is not so much qualitative as temporal and uses the biological concept of "encystation" as a metaphor to describe Israeli cordoning off and obliteration of the Palestinian population in both Palestine and Gaza:

The difference [between the walling of Gaza and that of the West Bank] is temporal rather than qualitative. [...] Gaza, like the Gazan population, has been judged expendable by Israel; its groundwater is salinated and heavy with pollutants and it does not have the biblical aura that makes 'Judea' so desirable to religious ethno-nationalists. It would be difficult - politically, practically and ideologically - to do with the people of the West Bank what has been done with those of Gaza [...] but this may simply be a matter of waiting for the opportune moment. [...] The question of whether and when Israel will opt for surgical intervention depends on many factors, but the equipment for removing the cyst is already at hand. (10-4)

The border as cyst to encircle, quarantine, and then remove malevolent elements in the body, is a concept used here metaphorically to describe the reality of Palestinian bare life $\mathrm{f}^{7}$ exposed to Israeli state violence. It also functions as a shared trope for Palestinian writers living on both sides of fragmented spaces. However, as with other cases of Partition literature, Palestinian writers also reinvest the border in order to construct an alternative (or "counterfactual") hyphenated Palestinian geography that would subvert the current partitioning of the land. ' Their imaginary borders are no longer the ones that divide but unite, not only Palestinians together, but also Palestine with humanity at large.

In Gaza Writes Back (2014), Refaat Alareer emphasizes the imperative to remember and rescue Palestine textually in order to offer through imaginary moves other futures than those delineated by political agendas and road maps. In this sense, the back in the title is not only a reference to The Empire Writes Back (Ashcroft, Griffiths, and Tiffin) and postcolonial theory, but it also carries with it the notion of reverting back to historic Palestine. As Alareer stated: "Theirs, while it sometimes is rendered metaphorically, can be a beautiful reality. Palestine is a martyr away, a tear away, a missile away, or a whimper away. Palestine is a story away" (15). In this elegiac passage, Alareer indicates that Palestine is not where you think it is. It is not to be found in this martyr, this tear, missile, whimper, or story; it is always in the making, à venir. Kept in this state of indeterminacy, always "a story away," the future of the Palestinian nation is a "future anterior" as Jacques Derrida has it in De la grammatologie and in other works, a future that is aleatory and open. Thus, the future of the Palestinian nation as " $a$ venir" is a promising one, not only because it is pressing forward, but also because the assertion of its fundamentally

7. The concept of "bare life" is borrowed from Giorgio Agamben who used it to describe the "extra-territoriality" of people living within the border of a nation but who do not share the same conceptual and legal rights as other citizens do.

8. Critics have emphasized the tendency in Partition literature towards the production of counterfactual narratives, in other words narratives which are not utopias, but which clearly refuse to abide by the political geography of partition (see Bartolovich; Bernard "Forms of Memory"; Gopal).

9. For a comparative literary approach to the question of Partition, see Cleary. 
Minding (About) the Gazan Border in Contemporary Palestinian Literature

indeterminate and immeasurable nature precludes the formation of an autotelic and exclusionary national imagination. ${ }^{10}$

While reaffirming the present reality of the border against the postcolonial idealistic narrative of borderless and hybrid states, Gazan writers redefine it not as a divisive element but rather as an element of the collective imaginary and use the border as a literary trope connecting them with other Palestinians, who share similar memories and experiences of the border. Whether they take the form of novels or short stories, in Arabic or in English, from authors based inside or outside Gaza, descriptions return to the border as a no man's land, as a dystopian "lieu de mémoire" painfully reminding characters of a land lost and redrawn by and for others, and as a liminal space where social inequalities between Palestinians and Israelis are reasserted. ${ }^{11}$

These descriptions in prose are also found in the poetry of the Palestinian-American poet Susan Abulhawa whose poem "Wala" recounts the humiliation endured by Palestinians at Israeli checkpoints, or in the travel literature of Rajah Shehadeh whose Palestinian Walks (2007) and Rift in Time (2010) not only highlight the violence of the imposition of the Israeli border on the Palestinian landscape and people, as also analyzed by Eyal Weizman in Hollow Land, but also redraw a cartography of Palestine beyond the borders, by recalling the Ottoman mapping of historic Palestine and by extending the gaze beyond man-made landscapes to describe natural landscapes: "Driving beyond Ramallah, we had passed numerous other borders, borders within borders. Everywhere I looked I could see borders, barbed wire and watch towers. The best antidote to the claustrophobia we Palestinians feel while attempting to cross the many borders Israel has created is to focus our attention on the physical expanse of the land" (Shehadeh, A Rift in Time 54-5).

This tropological convergence highlights the timeliness and relevance of a comparative methodology when engaging with Palestinian literature, which cannot and must not be approached piecemeal, lest literary criticism repeat the discourse of Partition imposed by local and international politics between the West Bank and Gaza, and between Israel and Palestine. Literature does not only provide a platform for the expression of a shared experience of space, as in the case of claustrophobia for instance, it also redefines space as a contact zone. When the movements of people are impeded, literature may still travel across borders.

Gazan writers do not only reconfigure the Palestinian cartography and respond to the Israeli politics of fragmentation with the creation of an imagined continuous geography, they also challenge the existence of a border between Palestine and Israel and so the existence of two separate states. ${ }^{12}$ As Rajah Shehadeh rightly pointed out: "By creating this surfeit of borders, Israel has made a mockery of them and finally brought

10. "For that future world and for that within it which will have put into question the values of sign, word, and writing, for that which guides our future anterior, there is as yet no exergue" (Derrida 5). ["Pour ce monde à venir et pour ce qui en lui aura fait trembler les valeurs de signe, de parole et d'écriture, pour ce qui conduit ici notre futur antérieur, il n'est pas encore d'exergue" (Grammatologie 14)].

11. I would suggest here a comparison of the short-story "A Journey in the Opposite Direction," written by Atef Abu Saif from Gaza and in Arabic, with Nour Al-Sousi’s short-story "Will I ever get out?" written from Gaza again but directly in English, the three long chapters (6 to 9) in the Arabic novel al-Sayyida min Tal Abib (trans. The Lady of Tel Aviv) written by the exile writer Raba'i al-Madhoun, and the novel Out of it written in English by a British-Palestinian author, Selma Dabbagh, living in London.

12. Opposing partition, some social analysts and historians, as well as political activists, have come up with the proposal of a one-state solution (see Tilley; Abunimah; Hochberg; Hazan and Sivan). 
home the point that the only real borders are those which we come to accept" ( $A$ Rift in Time 55). Opposing the rhetoric of a "natural" separation which presents the existence of two separate states as something organic to the land itself, using nature, such as the Jordan Valley, to establish and justify borders, Palestinian writers emphasize their artificiality and resituate them in history.

In al-Madhoun's Al-Sayyida min Tall Abib (2009), recently translated as The Lady from Tel Aviv (2013), the main character Walid Dahman meets with the lady from Tel Aviv, Dana Newman, on board a plane, where land borders cease to have a tangible reality. Dana raises the issue of the partition between Palestine and Israel during the flight and this is the only place in the novel where this reference appears. However, as the plane lands, and before they go their separate ways, Dana launches an elegiac complaint related to the ironic predicament in which both Palestinians and Israelis are caught: "In this country where you and I will separate and go our own ways, there is only one land. Only one place to live, only one house. Even so, when the sun rises over the place and casts its rays across the land, you see two shadows. Walid, you and I are two shadows thrown together in a single place" (92).

Delinking state with land, disconnecting historical from geological and natural geographies, this remark highlights the artificial nature of the separation and suggests that the project of an integrated state of Palestine constitutes a more viable future. Crucially, Palestinian authors revert the balance between fiction and reality, they defamiliarize the familiar and familiarize the strange, reframing existing borders as artificial creations and figments of the imagination, while promoting their own imagined or fictional geography as the only viable reality.

\section{Opening Up}

Gazan literature is not only suturing broken territories, thus contesting the neo-colonial cartography of the region, it also seeks to hyphenate the local with the global and to think global connections from local and secluded space, replicating the "ground-up" approach advocated by Francesca Orsini in her new mapping of world literature. ${ }^{13}$ Thus the open-air prison that Gaza has become remains intensely connected with the rest of the world by resorting to a shared semiology. ${ }^{14}$

In works of fiction, Gazan authors have used forms, formats, language, and other diegetic tools to reach across to a wider audience. Atef Abu Saif remarks in his introduction to the collection of short stories he edited that concision is a formal characteristic

13. In her article entitled “The Multilingual Local in World Literature," Francesca Orsini suggests a new approach to world literature that would save the field from its impoverishing and dangerous associations with the hegemonic structures of world capitalism. Instead of resorting to what she calls the "panoptic" gaze used to this day and that provides a cartography of world literature organized from above and between centres and peripheries, Orsini argues that, by endorsing a ground-up approach, we may give their dues to the multilingual specificities of locales and to their cross-sectional articulations of differences, while connecting them to the rest of the world. Thus the local becomes, according to her frame of reference, the best ally to think difference, and to remain attuned to the complexity of the world.

14. This notion that what happens in Palestine at least partially depends on larger-scale issues, such as globalization and the geo-strategic concerns of regional and international powers, has been documented by historians (Collins). I suggest here a different perspective, which is not to focus for instance on how Gazan production is shaped by global literary trends but rather on how it actively seeks to resonate with other local concerns worldwide. In other words, I would like to argue that Gazan literature is "wordly," in the sense that Edward Said gave to the term, as a literature that cannot be dissociated from politics and ideology, and, in the sense of being "cosmopolitan," of travelling world-wide and of being able to connect with the concerns of other people who are victims of the same politics of subjugation, be it ethnic, racial, political, economic, sexual, or social. 
of Gazan writing. The reason is practical and has to do with facilitating the passage the copying, transporting of stories, and the circumventing of censorship - from Gaza to publishing houses located in Jerusalem. He contends that "as was said in Palestinian circles abroad, [Gaza] became the "exporter of oranges and short-stories" (The Book of Gazax). There is a play on words in Arabic because the verb export (saddara) and publish (asdara) come from the same root (sa-da-ra). In other words, the form was chosen for its capacity to circulate, to cross borders, to circumvent barriers, to elude power. It is of no coincidence that still today Gazan writers tend to write in shorter forms, while Palestinians and Gazans from abroad, whether in Arabic or English, have more readily adopted the form of the novel. This tendency is reinforced by the dissemination of literature in electronic format, which privileges short stories and poetry.

E-publishing, blogging, and sharing on social media have dramatically quickened the pace of literary circulation, especially in short formats and extracts, and created a sense of continuity across and above the borders cutting through Palestinian territory. The perception that Palestinians may read the same electronic literature simultaneously is indicative of what Benedict Anderson defines as an "imagined community," which may be specified here as a "virtual community," no matter how embattled that community has become. However, its "virtual" nature remains highly problematic and cannot be substituted for the creation of a "real" continuity and free circulation. Furthermore, as Laetitia Nanquette argued in her article on Iranian literary blogging, the level of circulation and inter-reading between writers inside Iran and the Iranian diaspora remains quite low. The blogging revolution was both short-lived and more or less followed the borders of the nation. ${ }^{15}$ Similarly, inter-reading between diasporic Palestinians and $\mathrm{Pa}-$ lestinians living in Israel and the Occupied Territories should not be taken for granted. First, Palestinian writers in English do not circulate their full texts on their blogs (when they have one) but still rely on hard-copy publications, and they do not necessarily know or work closely with Palestinian writers from inside. Events, such as PalFest (the Palestine Literary Festival), are more likely to foster interactions and create shared platform for creation (such as creative writing workshops) than electronic media alone.

The PalFest bilingual website (Arabic/English) indicates a total of 146 participants between 2008 and 2015. Its 2015 annual report lists the names of 35 artists and writers participating in the festival, with 18 coming from the West Bank and Gaza, 2 Palestinian-American, and 15 internationals, from the Middle East, the USA, the UK, Italy, and Sri Lanka. Recreating cultural connections, broken by decades of military occupations, amongst Palestinians and between Palestinian and international artists, is indeed one of the stated aims of PalFest, which also strives to relay a fraction of the Palestinian experience to the visiting artists from abroad by taking them across historic Palestine, and to profile new Palestinian talent by inviting them to the stage. The project is thus interlingual, international, and intergenerational. The festival is funded through private donations and the financial support of both Palestinian and international donors. The cultural events and the talks with Palestinians activists, journalists, and scholars, are

15. I would like to thank Laetitia Nanquette, from The University of New South Wales, Australia, for sharing her original and highly stimulating article on "Iranian literary blogs and the evolution of the literary field: towards a globalization of contemporary Iranian literature?" with me. At the moment of publication of this CES issue, the draft of Laetitia Nanquette's article that I read has not been published yet but has been submitted to the journal Diaspora under the title above mentioned. 
staged in the cities of Bethlehem, Gaza, Haifa, Jerusalem, Nablus, and Ramallah, and are open to all for free, with an estimated 1,200 visitors for the 2015 edition of the festival.

Such festivals connect an international population with local inhabitants and defy a series of barriers, including the language barrier, by providing simultaneous translations for all public events, and by publishing an anthology in Arabic of the poetry, prose, plays, or screenplays, recited in English during the performances. The anthology is distributed for free at the entrance of each site and is downloadable in pdf format as well. The barrier of the border is also evaded by the use of satellite transmission. As for two consecutive years Gazan artists were denied entry into the West Bank, they held three events under the banner of the 2015 PalFest in Gaza itself and a talk on Skype with Mourid Barghouti, a major Palestinian poet and writer in Arabic based in Cairo in the 1970s and who had returned there after seventeen years of exile from Egypt between 1977 and 1994. Thus PalFest cuts across Israeli blockades, checkpoints, and settlers' walls, but it also connects Palestine with the larger literary world in Arabic and in English by fostering extensive coverage in traditional media, such as Al Jazeera English, $\mathrm{Al}$ Jazeera Arabic, Middle East Monitor, Jadaliyya, and Mondoweiss, and in social media. Not only has PalFest its own Facebook page but it also encourages international visitors to comment and tweet on their visits and share on the own Facebook timeline, which can then very rapidly be quoted and shared again on the PalFest page or other users' pages. Thus an electronic intertextual world is unfolding gradually and with no strict pre-determined shape and directions, depending rather on what the artists choose to document. However, such cultural events are time-bound and once the festival is finished the intensity of exchanges plummets rapidly until the following year comes around. The long-term effect of participating in the festival and how this experience of Palestine may percolate in their works is less easily quantifiable, even if all writers assure it shall (Palfest Annual Report 2015 28).

If imaginary narrations of the nation transgress borders imposed on the ground, reconfigure and enact alternative visions suturing the parts of Palestine divided by Israeli invasions and eaten away by Israeli settlements, they also remain acutely aware of the danger of creating a virtual Palestine that would end up supporting the perpetuation of the status quo or of further fragmentation. Even so and beyond the imagined recreation of historic Palestine or the virtual establishment of an integrated Palestine, social media offer Gaza an open window onto the rest of the world and can be used in order to compete with the representations of Gaza sold by mass media. Crucially, with their focus on the every day life and their aspiration to normalcy, Gazan writers and artists block the unsound curiosity of the outsider's gaze, her/his thirst for ready-made exoticism of the harem-like type or for the sublime thrill of vicarious violence, and thus produce and circulate images that may truly compete with the inundation of mass-media snapshots, which merely skim over reality or remain at its borders. 


\section{Works Cited}

Abulhawa, Susan. "Wala." My Voice Sought the Wind. Charlottesville, VA: Just World Books, 2013. 39-43.

Aвuniman, Ali. One Country. A Bold Proposal to End the Israeli-Palestinian Impasse. New York: Metropolitan, 2006.

Aвu SaIF, Atef, ed. The Book of Gara. London: Comma, 2014.

—. "A Journey in the Opposite Direction." Atef Abu Saif 1-18.

Afzal-Khan, Fawzia and Kalpana Seshadri-Crooks, eds. The Pre-Occupation of Postcolonial Studies. Durham, NC: Duke UP, 2000.

Agamben, Giorgio. Homo Sacer: Sovereign Power and Bare Life. 1995. Stanford: Stanford UP, 1998.

Alareer, Refaat, ed. Gaza Writes Back: Short Stories from Young Writers in Gaza, Palestine. Charlottesville, VA: Just World Books, 2014.

—. "Gaza Writes Back: Narrating Palestine." Biograpby 37.2 (Spring 2014): 524-37.

Al-Ghul, Asmaa. "You and I." Abu Saif 97-104.

Al-Madhoun, Raba'i. The Lady of Tel Aviv. Trans. Elliott Colla. London: Telegram, 2013. Trans. of al-Sayyidah min Tall Abib, 2009.

AL-Sousi, Nour. "Will I ever get out?" Alareer 71-4.

ALI, Sarah. "The Story of the Land." Alareer 59-64.

ANDERson, Benedict. Imagined Communities: Reflections on the Origin and Spread of Nationalism. London: Verso, 1983.

Bartolovich, Crystal. "History After the End of History: Critical Counterfactualism and Revolution." New Formations 59 (2006): 63-80.

Bernard, Anna. "Forms of Memory: Partition as a Literary Paradigm." Trauma and Memory issue, Alif: Journal of Comparative Poetics 30 (2010): 9-33.

—. Rhetorics of Belonging. Liverpool: Liverpool UP, 2013.

Bernard, Anna, Ziad Elmarsafy and Stuart Murray, eds. What Postcolonial Theory Does not Say. New York: Routledge, 2015.

Bey, Hakim (Peter Lamborn Wirson). T.A.Z.: The Temporary Autonomous Zone, Ontological Anarchy, Poetic Terrorism. Brooklyn, NY: Autonomedia, 1991.

Bнавна, Homi. The Location of Culture. London: Routledge, 1994.

Bowman, Glenn. "Encystation: Containment and Control in Israeli Ideology and Practice." Journal of Palestine Studies 44.3 (2015): 6-16.

Cleary, Joe. Literature, Partition, and the Nation State: Culture and Conflict in Ireland, Israel, and Palestine. Cambridge: CUP, 2002.

Collins, John. Global Palestine. New York: Columbia UP, 2011.

DabBagh, Selma. Out of it. London: Bloomsbury, 2011.

DARiwish, Mahmoud. "The earth is closing on us." Victims of a Map. Trans. Abdullah al-Udhari. London: Al Saqi Books, 1984.

DerRidA, Jacques. Of Grammatology. Trans. Gayatri Chakravorty Spivak. Baltimore: John Hopkins U P, 1997. Trans of De la grammatologie. Paris: Les éditions de Minuit, 1967.

Gopal, Priyamvada. The Incaan English Novel: Nation, History and Narration. Oxford: OUP, 2009.

Hamarneh, Walid. "Some Narrators and Narrative Modes in the Contemporary Arabic Novel." The Arabic Novel since 1950: Critical Essays, Interviews, and Bibliography. Ed. Roger Allen and Issa Boullata. Cambridge, MA: Dar Mahjar Pub. \& Distribution, 1992. 205-36.

Hassan, Salah. "Undertaking Partition: Palestine and Postcolonial Studies." Journal X: A Journal in Culture and Criticism 6.1 (2001): 9-45.

Hazan, Eric, et Eyal Sivan. Un état commun. Entre la mer et le Jourdain. Paris: Éditions de la Fabrique, 2012.

Hochberg, Gil. In Spite of Partition. Princeton, NJ: Princeton UP, 2007.

JAYYUsi, Salma Khadra. Modern Arabic Fiction, An Anthology. New York: Columbia UP, 2005.

Loomba, Ania et al., eds. Postcolonial Studies and Beyond. Durham, NC: Duke UP, 2005.

Massad, Joseph. "The 'Post-Colonial' Colony: Time, Space, and Bodies in Palestine/Israel." AfzalKhan and Seshadri-Crooks. 311-47.

OrsinI, Francesca. "The Multilingual Local in World Literature." Comparative Literature 67.4 (2015): 345-74.

QArmout, Nayrouz. “The Cloak of the Sea.” Abu Saif 19-29.

SAID, Edward. The Question of Palestine. 1979. New York: Vintage Book, 1992.

-. After the Last Sky. New York: U of Columbia P, 1999.

ShenadeH, Rajah. A Rift in Time. Travels with my Ottoman Uncle. London: Profile Books, 2010.

—. "Diary of an Internal Exile. June 5, 2011." Seeking Palestine. Ed. Johnson Penny and Raja Shehadeh. Northampton, MA: Olive Branch, 2013. 94-6.

Sнонат, Ella. "Notes on the Post-Colonial." Afzal-Khan and Seshadri-Crooks 126-40. 
SteIn, Rebecca. "The Ballad of the Sad Cafe: Israeli Leisure, Palestinian Terror, and the Post/colonial Question.” Loomba 317-37.

Tilley, Virginia. The One-State Solution: A Breakthrough for Peace in the Israeli-Palestinian Deadlock. Ann Arbor, MI: U of Michigan P, 2005.

Weizman, Eyal. Hollow Land: Israel's Architecture of Occupation. London: Verso, 2007.

Williams, Patrick. "'Outlines of a Better World': Rerouting Postcolonialism." Rerouting the Postcolonial: New Directions for the New Millenium. Ed. Janet Wilson, Cristina Sandru, and Sarah Lawson Welsh. London: Routledge, 2010. 86-98.

—. "Gaps, Silences, and Absences: Palestine and Postcolonial Studies." Bernard, Elmarsafy, and Murray 87-104. 